\title{
Integration of Organic and Mineral Nutrient Sources Enhances Wheat Productivity, Soil Health and Profitability in western Uttar Pradesh
}

\author{
Vineet Singh $^{1}$, N.S. Rana ${ }^{1}$, Ravindra Kumar ${ }^{2}$, Vivek ${ }^{1}$, B.P. Dhyani ${ }^{3}$, R.K. Naresh ${ }^{1 *}$, \\ Arun Kumar ${ }^{1}$ and Nihal Chandra Mahajan ${ }^{1}$
}

${ }^{1}$ Department of Agronomy, ${ }^{2}$ Department of Cell Biology, ${ }^{3}$ Department of Agronomy, Sardar Vallabhbhai Patel University of Agriculture and Technology, Meerut-250110, U.P., India

*Corresponding author

\begin{abstract}
Keywords
FYM, Biofertilizers, Yield attributes, Organic carbon.

Article Info

Accepted:

26 September 2017

Available Online:

10 October 2017 $\mathrm{T}_{1^{-}}$Control, $\mathrm{T}_{2^{-}} 100 \% \mathrm{NPK}, \mathrm{T}_{3}-75 \% \mathrm{NPK}+\mathrm{FYM}, \mathrm{T}_{4^{-}}-75 \% \mathrm{NPK}+\mathrm{FYM}+\mathrm{PSB}+$ Azotobactor, $\mathrm{T}_{5^{-}} 100 \% \mathrm{NPK}+\mathrm{Zn}, \mathrm{T}_{6^{-}} 100 \% \mathrm{NPK}+\mathrm{Zn}+\mathrm{Mn}, \mathrm{T}_{7}-100 \% \mathrm{NPK}+\mathrm{Zn}+\mathrm{Mn}$ $+\mathrm{Fe}, \mathrm{T}_{8}-75 \% \mathrm{NPK}+\mathrm{FYM}+\mathrm{PSB}+$ Azotobactor $+\mathrm{Zn}+\mathrm{Fe}+\mathrm{Mn}, \mathrm{T}_{9-1} 125 \% \mathrm{NPK}, \mathrm{T}_{10^{-}}$ $125 \% \mathrm{NPK}+\mathrm{Zn}, \mathrm{T}_{11}-125 \% \mathrm{NPK}+\mathrm{Zn}+\mathrm{Mn}, \mathrm{T}_{12}-125 \% \mathrm{NPK}+\mathrm{Zn}+\mathrm{Mn}+\mathrm{Fe}, \mathrm{T}_{13}-100 \%$ $\mathrm{NPK}+\mathrm{FYM}+\mathrm{PSB}+$ Azotobactor $+\mathrm{Zn}+\mathrm{Fe}+\mathrm{Mn}$ and $\mathrm{T}_{14}-50 \% \mathrm{~N}+100 \% \mathrm{PK}+\mathrm{FYM}+$ $\mathrm{PSB}+$ Azotobactor $+\mathrm{Zn}+\mathrm{Fe}+\mathrm{Mn}+\mathrm{LCC}$ based $\mathrm{N}$ top dressing. The results revealed that the addition of $100 \%$ NPK + FYM + PSB + Azotobactor+ $\mathrm{Zn}+\mathrm{Fe}+\mathrm{Mn}$ recorded significantly higher value of growth, yield attributes and nutrient uptake in terms of plant height $(\mathrm{cm})$, dry matter accumulation $\left(\mathrm{g} \mathrm{m}^{-1}\right)$, number of effective tillers $\left(\mathrm{m}^{-2}\right)$, 1000-grain weight $(\mathrm{g})$, protein content $(\%)$ and grain yield $\left(58.40 \mathrm{q} \mathrm{ha}^{-1}\right)$ followed by $125 \% \mathrm{NPK}+\mathrm{Zn}$ + Mn grain yield $\left(57.9 \mathrm{q} \mathrm{ha}^{-1}\right)$. The total uptake of nitrogen, phosphorus, potassium and micro nutrients $(\mathrm{Zn}, \mathrm{Fe}, \mathrm{Mn})$ and content of organic carbon increase with the combined application of organic and inorganic with biofertilizer. Integration of $100 \%$ NPK + FYM + Azotobactor $+\mathrm{Zn}+\mathrm{Mn}+\mathrm{Fe}$ was found more productivity and remvaerative with the higher residual soil fertility status after wheat crop. The integration of mineral fertilizers with FYM not only escalated the grain yield of wheat but also enhanced micro nutrients uptakes and their recoveries over mineral fertilizer alone.
\end{abstract}

\section{A B S T R A C T}

Integrated plant nutrition management system is one of the best methods of plant nutrition, which enhances the farm productivity. To evaluate the effect of organic and mineral nutrition on wheat production, a field study was conducted at Sardar Vallabhbhai Patel University of Agriculture and Technology, Meerut. The experiment was arranged according to Randomized Block Design in three replications with fourteen treatments viz.;

\section{Introduction}

Wheat (Triticum aestivum L.), the second most important food crop of the world in terms of area, production and nutrition, meets 20 per cent of the total food, 19 per cent of calories and 20 per cent of protein requirements of the global population besides being a major source of dietary fibre in human nutrition since decades. It was grown in diverse environments across the globe over an area of 277 million hectares producing 654 million metric tons of grains with an average productivity of 3 tons $\mathrm{ha}^{-1}$. In India, wheat occupied an area of 31.0 million hectare and produced of 88.9 million tons of grains with productivity of $2872 \mathrm{~kg} \mathrm{ha}^{-1}$ during 2015-16 (Anonymous, 2016). Amongst food-grains, it 
shared about $21 \%$ of area and $34 \%$ production of the country. Use of chemical fertilizers though has increased the crop yield, it has several ill effects on soil, environment as well as human and animal health hazards besides making the crop productivity unsustainable in the long run. Indiscriminate use of high levels of $\mathrm{N}, \mathrm{P}$ and $\mathrm{K}$ fertilizers, often leads to nutritional imbalance particularly for micronutrients which ultimately cause deterioration in physicochemical properties of soil and steadily decrease crop yield (Gupta et al., 2000). Soil productivity has gone down, and now time has come to supplement these chemical fertilizers with organics to sustain the fertility and productivity of the soils Behera et al., (2009).

This calls for development of integrated nutrient management systems (INMS) where chemical fertilizer is supplemented through organic source of plant nutrients, viz. well decomposed FYM, sugar factory press mud cake, green manures and biofertilizers for improvement and maintenance of soil fertility leading to sustained crop production. In wheat production, micronutrients play a vital role in the yield improvement $\mathrm{Zn}, \mathrm{Mn}, \mathrm{Fe}, \mathrm{B}, \mathrm{Cu}$ and Mo are known to be the most important micronutrients for higher plants. Micronutrients occupy a major portion as they are essential for increasing the growth and yield attributes of plant. Their importance increases due to their role in plant nutrition and increasing the soil productivity. Thus, judicious combination of organics, biofertilizers and chemical fertilizers helps to maintain soil productivity to alleviate the problem has become the need of the hour to address multifarious issues. Organic manures supports soil biological activities besides improving soil structure, and other physicochemical properties of soil Devi et al., (2013). An increase in availability of micronutrients like $\mathrm{Zn}, \mathrm{Cu}, \mathrm{Fe}$ and $\mathrm{Mn}$ and OM- bound fractions of micronutrients with the addition of organic and mineral fertilization have been advocated by Herencia et al., (2008). The present study was therefore, conducted to evaluate the efficacy of organic and inorganic nutrient sources and to sought out the suitable combination of mineral and organic fertilizers for higher wheat production, soil health and profitability.

\section{Materials and Methods}

The field experiment was conducted during the rabi season of 2015-16 at Crop Research Centre of Sardar Vallabhbhai Patel University of Agriculture and Technology, Meerut, $\left(29^{\circ}\right.$ $13^{\prime} \mathrm{N}, 77^{0} 68^{\prime} 43 \mathrm{E}, 237 \mathrm{~m}$ above mean sea level) U.P., India. Climate is semi-arid subtropical with extremes of hot weather in summer and cold in winter season. There is gradual decrease in mean daily temperature from October reaching as low as $2-4{ }^{0} \mathrm{C}$ in January and further a gradual increase is registered from February reaching as high as $43-45^{\circ} \mathrm{C}$ in May. The rains are predominantly caused by south-west monsoon which sets in the last week of June, reaches its peak in JulyAugust and withdraws by the end of September. The area receives $862 \mathrm{~mm}$ of rains annually on an average, of which $90 \%$ is confined to rainy season (July-September). Soil of experimental field was sandy loam with $\mathrm{pH}$ of 8.3 , electric conductivity (EC) $1.7 \mathrm{dSm}^{-1}$, low in organic C $(0.41 \%)$, available $\mathrm{N}\left(174.8 \mathrm{~kg} \mathrm{ha}^{-1}\right)$, medium in available $\mathrm{P}$ $\left(13.7 \mathrm{~kg} \mathrm{ha}^{-1}\right)$ and $\mathrm{K}\left(245 \mathrm{~kg} \mathrm{ha}^{-1}\right)$. A range of mean weekly maximum temperature varied from $16.5^{\circ} \mathrm{C}$ to $40.2^{\circ} \mathrm{C}$, and the mean weekly minimum temperature ranged from $4.6^{\circ} \mathrm{C}$ to $22.7^{\circ} \mathrm{C}$ during $2015-16$. The total of $22.4 \mathrm{~mm}$ rainfall was received during crop season 2015-16. The experiment was laid out in RBD (Randomized Block design) with three replication. Studies were conducted with fourteen treatments viz., $\mathrm{T}_{1}$ - Control, $\mathrm{T}_{2}-100$ $\%$ NPK, $\mathrm{T}_{3}-75 \% \mathrm{NPK}+\mathrm{FYM}, \mathrm{T}_{4}-75 \%$ 
$\mathrm{NPK}+\mathrm{FYM}+\mathrm{PSB}+$ Azotobactor, $\mathrm{T}_{5-} 100 \%$ $\mathrm{NPK}+\mathrm{Zn}, \mathrm{T}_{6}-100 \% \mathrm{NPK}+\mathrm{Zn}+\mathrm{Mn}, \mathrm{T}_{7-}$ $100 \% \mathrm{NPK}+\mathrm{Zn}+\mathrm{Mn}+\mathrm{Fe}, \mathrm{T}_{8}-75 \% \mathrm{NPK}+$ $\mathrm{FYM}+\mathrm{PSB}+$ Azotobactor $+\mathrm{Zn}+\mathrm{Fe}+\mathrm{Mn}$, $\mathrm{T}_{9}-125 \% \mathrm{NPK}, \mathrm{T}_{10^{-}} 125 \% \mathrm{NPK}+\mathrm{Zn}, \mathrm{T}_{11^{-}}$ $125 \% \mathrm{NPK}+\mathrm{Zn}+\mathrm{Mn}, \mathrm{T}_{12}-125 \% \mathrm{NPK}+\mathrm{Zn}$ $+\mathrm{Mn}+\mathrm{Fe}, \mathrm{T}_{13}-100 \% \mathrm{NPK}+\mathrm{FYM}+\mathrm{PSB}+$ Azotobactor $+\mathrm{Zn}+\mathrm{Fe}+\mathrm{Mn}$ and $\mathrm{T}_{14}-50 \% \mathrm{~N}$ $+100 \% \mathrm{PK}+\mathrm{FYM}+\mathrm{PSB}+$ Azotobactor $+\mathrm{Zn}$ $+\mathrm{Fe}+\mathrm{Mn}+\mathrm{LCC}$ based $\mathrm{N}$ top dressing. Wheat crop was sown with the row spacing of $22.5 \mathrm{~cm}$. five irrigations $(60 \mathrm{~mm}$ irrigation in each) were applied at five critical phenological stages. In regards to fertilizer application of the crop, $150 \mathrm{~kg} \mathrm{~N}, 75 \mathrm{~kg} \mathrm{P}_{2} \mathrm{O}_{5}$ and $60 \mathrm{~kg} \mathrm{~K} \mathrm{~K}_{2} \mathrm{O}$ were applied as recommended dose. Out of which, $1 / 2 \mathrm{~N}$ and full dose of $\mathrm{P}_{2} \mathrm{O}_{5}$ and $\mathrm{K}_{2} \mathrm{O}$ were applied as basal at the time of sowing by broadcasting method. The remaining $1 / 2$ dose of $\mathrm{N}$ was applied in two equal splits at CRI and late tillering stages. Organic manure, FYM, and bio fertilizer Azotobactor and PSB were used as per treatment. Variety of wheat is DBW 17 was sown on 28 November, 2015. Five spike selected randomly were threshed manually, grains were counted and data presented as grains per spike. The sample of 1000-grains collected from each plot, weighed and presented as gram. Total bundle weight was recorded from each plot at the time of harvesting. The crop was threshed and grain were weighed and presented as quintal per hectare. A representative sample for grain and straw was taken separately to determine respective dry matter production for each treatment plot wise. The uptake of individual nutrient was calculated by multiplying dry matter yield and respective nutrient content Meteorological data, viz., rainfall, relative humidity, maximum and minimum temperature, were recorded from Agrometeorological observatory, Meerut. Data on yield attributes, grain yield, and harvest index were recorded at crop maturity. Standard procedures were used for chemical analysis of soil and plant sample. The data were analyzed by using the 'Analysis of Variance Technique' as per the procedures described by Gomez and Gomes (1984). The treatment means were compared at $5 \%$ level of significance

\section{Results and Discussion}

\section{Growth and yield attributes}

Applications of organic with inorganic sources of fertilizer at any level were found to improve the growth and yield attributing character (Table 1) in comparison to control. Nutrient had significant effect on plant height during the year of investigation. Application of different nutrient management practices influenced the plant height significantly over the control. The application of $125 \%$ NPK + $\mathrm{Zn}+\mathrm{Mn}+\mathrm{Fe}$ recorded the maximum plant height which was at par with $100 \% \mathrm{NPK}+$ $\mathrm{FYM}+\mathrm{PSB}+$ Azotobactor $+\mathrm{Zn}+\mathrm{Fe}+\mathrm{Mn}$. The control plots resulted significant reduction in plant height compared to other treatments at harvest. Such a higher plant height in $100 \%$ NPK with organic manures and bio-fertilizers can be associated with sufficient nutrient supply at the active growth stage. Similar results of increased plant height were also reported by Kumar and Ahlawat (2004), Tulsa Ram and Mir (2006), Thakral et al., (2003). Dry matter production in crop is a function of current photosynthesis. Balanced nutrition helps in achieving higher dry matter accumulation through enhanced canopy cover which ultimately increased higher amount of assimilated through higher rate of current photosynthesis. Total plant stand, plant height, number of effective tillers characters will ultimately affect dry matter accumulation by crop. Nutrient management treatments had significant effect on dry matter accumulation. Further, perusal of the data revealed that dry matter accumulation $\left(\mathrm{g} \mathrm{m}^{-1}\right)$ decreased significantly with nutrient doses from $100 \%$ 
NPK with all other nutrient inputs (FYM + Bio fertilizers + micronutrient) to control. At harvest, $100 \%$ NPK alongwith FYM, biofertilizers, $\mathrm{Zn}, \mathrm{Mn}$ and $\mathrm{Fe}$ with all other nutrient inputs crop accumulated more dry matter than other nutrient options. Highest dry matter accumulation was recorded in $125 \%$ $\mathrm{NPK}+\mathrm{Zn}+\mathrm{Mn}+\mathrm{Fe}$ which was statistically at par with $100 \%$ NPK along with FYM, biofertilizers, $\mathrm{Zn}, \mathrm{Mn}$ and $\mathrm{Fe}$ at harvest during 2015.16. Minimum dry matter accumulation was recorded in control plots. The application of organic and inorganic sources of nutrients with $100 \%$ NPK also produced better growth parameters viz., plant height, number of effective tillers and finally dry matter. Similar results were also reported by Jakhar et al., (2006), Sepat et al., (2010). The number of effective tillers $\left(\mathrm{m}^{-2}\right)$ increased up to at 60 DAS and started declining their after at 90 DAS and at harvest. The highest number effective tillers at 90 DAS were recorded in $125 \% \mathrm{NPK}+\mathrm{Zn}+\mathrm{Mn}+\mathrm{Fe}$ which was statistically at par with $100 \%$ NPK along with FYM, biofertilizers, $\mathrm{Zn}, \mathrm{Mn}$ and Fe at harvest during 2015.16. Lowest numbers of tillers were recorded in control plots. Such a higher number of effective tillers in these treatments can be linked with optimum supply of essential nutrients at active tillering stage. Similar results were also reported by Singh and Agarwal (2001) and Jat et al., (2013).

\section{Yield}

The yield of a crop depends upon the source sink relationship and is the cumulative expression of various growth parameters and yield attributing components viz; 1000- grain weight. Maximum of 1000- grain weight and protein content (\%) was recorded in $125 \%$ $\mathrm{NPK}+\mathrm{Zn}+\mathrm{Mn}+\mathrm{Fe}$ which was found statistically at par with $100 \% \mathrm{NPK}+\mathrm{FYM}+$ $\mathrm{PSB}+$ Azotobactor $+\mathrm{Zn}+\mathrm{Fe}+\mathrm{Mn}$. The effect of $100 \%$ NPK + FYM+ PSB+ Azotobactor $+\mathrm{Zn}+\mathrm{Fe}+\mathrm{Mn}$ being statistically at par with $125 \% \mathrm{NPK}+\mathrm{Zn}+\mathrm{Mn}$ $+\mathrm{Fe}$ and was superior to control in respect of yield attributing characters (Table 1). More yield attributes were found in the treatment where organic and inorganic sources of plant nutrients were applied over control. Higher level of nutrients improved the fertility level of soil and creates congenial condition for better growth and development thus improved the yield attributes. These results are in conformity with those reported by Sen et al., (2003), Singh et al., (2007) and Barthwal et al., (2013).

Application of nutrient management treatments significantly increased the grain, yield of wheat during the years of experimentation. The grain, yields were recorded significantly higher in the treatments $125 \% \mathrm{NPK}+\mathrm{Zn}+\mathrm{Mn}+\mathrm{Fe}$ which was 58.70 $\mathrm{q} \mathrm{ha}^{-1}$ which was at par with $100 \% \mathrm{NPK}+$ $\mathrm{FYM}+\mathrm{PSB}+$ Azotobactor $+\mathrm{Zn}+\mathrm{Fe}+\mathrm{Mn}$. The magnitude of increase being highest of $30.4 \mathrm{q} \mathrm{ha}^{-1}$ or $107 \%$ with $125 \%$ NPK with Zn $+\mathrm{Mn}$ and $\mathrm{Fe}$ and $20.9 \mathrm{q} \mathrm{ha}^{-1}$ or $73.8 \%$ with $100 \%$ NPK.

Crop grown with $25 \%$ substitution of nitrogen through FYM or FYM and biofertilizers gave 2.8 and $4.0 \%$ higher yield than that grown with $100 \%$ NPK. The crop receiving 100\% NPK along with FYM, biofertilizers, Zn, Mn and $\mathrm{Fe}$ remaining at par with treatments having $125 \%$ NPK with micronutrients proved significantly better than $100 \%$ NPK. All the other treatments where 100\% NPK was supplemented with micronutrients resulted in significant increase in grain yield over $100 \%$ NPK being $5.8 \%$ with Zn, $8.7 \%$ with $\mathrm{Zn}+\mathrm{Mn}$ and $9.7 \%$ with $\mathrm{Zn}+\mathrm{Mn}+\mathrm{Fe}$. Further enhancement of NPK to $125 \%$ alone or with micronutrients produced significant effect over respective combinations with $100 \%$ NPK. Basal application of NPK along with biofertilziers and micro-nutrients coupled with LCC based nitrogen top 
dressing led to significant increase in yield being $3.8 \mathrm{q} \mathrm{ha}^{-1}(7.7 \%)$ over 100 NPK but remained significantly lower than the yield obtained with $100 \%$ NPK, FYM + biofertilizers + micronutrients $\left(58.4 \mathrm{q} \mathrm{ha}^{-1}\right)$. The crop receiving $100 \%$ NPK along with FYM, biofertilizers, $\mathrm{Zn}, \mathrm{Mn}$ and Fe remaining at par with treatments having $125 \%$ NPK with micronutrients proved significantly better than $100 \%$ NPK.

The beneficial effect of organic manures on grain, yields and yield attributing characters might be assigned to the fact that after proper decomposition and mineralization, these manures supplemented plant nutrients to the plants and also had solublising effect on fixed forms of nutrients in soil. Similar findings were also reported by Mubarak and Singh, (2011).The combination use of organic manures and chemical fertilizers enhanced the inherent capacity of soil as reported by Pandey et al., (2009), Verma, et al., (2010) and Meena et al., (2012), Singh and Singh (2005).

\section{Protein content}

Application of $125 \% \mathrm{NPK}+\mathrm{Zn}+\mathrm{Mn}+\mathrm{Fe}$ has proven the best with $10.40 \%$ Protein it was statistically at par with $100 \%$ NPK along with FYM, biofertilizers, $\mathrm{Zn}, \mathrm{Mn}$ and $\mathrm{Fe}$ (Table 1). The results indicate that integrated nutrient application through chemical fertilizer, FYM and bio- fertilizer improve the protein content in grain over control.

Similar results have been reported by Hasan and Kamal (1998). Nitrogen is most important factor which determines protein constituent of grain. It is essential for vegetative and reproductive stages. Nitrogen not only affects wheat productivity but also has a synergistic effect on quality of grain. Nitrogen is important constituent of protein, enzyme and chlorophyll and is involved in all processes associated with protoplasm, enzymatic reaction and photosynthesis (Tisdale et al., 1995).

\section{Nutrient uptake}

Nutrient uptake, a function of dry matter yield of components (grain/straw) and respective nutrient content, behaved similar to dry matter production and nutrient content under the influence of nutrient management practices. The crop fertilized with $125 \%$ NPK $+\mathrm{Zn}+$ $\mathrm{Mn}+\mathrm{Fe}$ highest total uptake of $\mathrm{N}(155.0 \mathrm{~kg}$ $\left.\mathrm{ha}^{-1}\right), \mathrm{P}\left(34.3 \mathrm{~kg} \mathrm{ha}^{-1}\right), \mathrm{K}$ (111.6kg ha $\left.{ }^{-1}\right), \mathrm{Zn}$ (600.8 $\left.\mathrm{g} \mathrm{ha}^{-1}\right)$, Mn (409.7 $\mathrm{g} \mathrm{ha}^{-1}$ ) and Fe $\left(1791.5 \mathrm{~g} \mathrm{ha}^{-1}\right)$ as against the lowest of 64.4 , 10.0, 35.2, $\mathrm{kg} \mathrm{ha}^{-1} 193.3 \mathrm{~g} \mathrm{ha}^{-1}, 129.4 \mathrm{~g} \mathrm{ha}^{-1}$ and $675.0 \mathrm{~g} \mathrm{ha}^{-1}$ respectively in crop receiving no fertilizer (Table 2).

Favorable effect of NPK application on nutrient uptake by wheat has also been reported by Rawat and Pareek (2003) of NPK by Pandey et al., (2009) Cakmak (2012) of Zn by Azotobacter and PSB by Rathor and Sharma (2010).The crop having highest accumulation also had highest dry matter assimilation and nutrient content which ascertained highest uptake of most of the nutrients. The highest uptake of macro and micro nutrients with $125 \% \mathrm{NPK}+\mathrm{Zn}+\mathrm{Mn}+$ Fe remained at par with $100 \%$ NPK along with FYM, biofertilizers, Zn, Mn, Fe proved significantly better than $100 \%$ NPK and lowest with no nutrient application.

Applications of $\mathrm{Zn}, \mathrm{Mn}$ and $\mathrm{Fe}$ alone or together with $100 \%$ NPK increased uptake over $100 \%$ NPK. This is in accordance to the kind of relationship between nutrient content in plant tissues and the concentration in growing medium, the soil. Application of fertilizers readily increases the availability of nutrient concerned in the soil solution thereby enhancing its absorption by the plant roots and further translocation to the site of action. 
Favorable effect of NPK on nutrient uptake of wheat has also been noted by Shivay et al., 2008). The beneficial effect of $\mathrm{Zn}$ and $\mathrm{B}$ when applied in conjunction with organic/inorganic/bio-fertilizers might have helped in increasing and balancing the availability of essential plant nutrients and organic fertilizers sustained it over a long time. Microbial decomposition of organic manure (FYM) with simultaneous release of organic acid which act as chelating agent might have facilitated the availability and absorption of micro-nutrients as indicated by plant nutrient content and residual soil fertility.

Table.1 Plant height, dry matter accumulation, effective tillers, 1000- grain weight, protein content and grain yield as influenced by different nutrient options

\begin{tabular}{|c|c|c|c|c|c|c|}
\hline Treatment & $\begin{array}{l}\text { Plant height at } \\
\text { harvest }(\mathrm{cm})\end{array}$ & $\begin{array}{c}\text { Dry matter } \\
\text { accumulation }(g) \mathrm{m}^{-1} \\
\text { At harvest }\end{array}$ & $\begin{array}{c}\text { Effective tillers } \\
\text { m }^{-1} 90 \text { DAS }\end{array}$ & $\begin{array}{l}1000 \text {-grain } \\
\text { weight (g) }\end{array}$ & $\begin{array}{c}\text { Protein } \\
\text { content }(\%)\end{array}$ & $\begin{array}{c}\text { Grain } \\
\text { Yield } \\
\left(\mathrm{q} \mathrm{ha}^{-1}\right)\end{array}$ \\
\hline $\mathbf{T}_{1}$ - Control & 61.5 & 678.0 & 205 & 28.7 & 9.6 & 28.3 \\
\hline $\mathbf{T}_{2}-100 \% \mathrm{NPK}$ & 75.2 & 1007.4 & 267 & 36.3 & 9.7 & 49.2 \\
\hline $\mathbf{T}_{3}-75 \% \mathrm{NPK}+\mathrm{FYM}$ & 75.9 & 1010.8 & 270 & 36.6 & 9.8 & 50.6 \\
\hline $\mathbf{T}_{4}-75 \% \mathrm{NPK}+\mathrm{FYM}+\mathrm{PSB}+$ Azotobactor & 76.4 & 1012.1 & 273 & 36.9 & 9.8 & 51.2 \\
\hline $\mathbf{T}_{5}-100 \% \mathrm{NPK}+\mathrm{Zn}$ & 77.2 & 1014.4 & 277 & 37.2 & 9.8 & 52.1 \\
\hline $\mathbf{T}_{6}-100 \% \mathrm{NPK}+\mathrm{Zn}+\mathrm{Mn}$ & 78.6 & 1017.4 & 285 & 38.2 & 10.0 & 53.5 \\
\hline $\mathbf{T}_{7}-100 \% \mathrm{NPK}+\mathrm{Zn}+\mathrm{Mn}+\mathrm{Fe}$ & 80.2 & 1021.2 & 290 & 38.5 & 10.0 & 54.0 \\
\hline $\begin{array}{l}\mathbf{T}_{8}-75 \% \text { NPK + FYM+ PSB+ Azotobactor+ } \\
\mathrm{Zn}+\mathrm{Fe}+\mathrm{Mn}\end{array}$ & 78.3 & 1013.0 & 281 & 37.8 & 10.0 & 53.3 \\
\hline $\mathbf{T}_{9}-125 \% \mathrm{NPK}$ & 84.5 & 1077.1 & 317 & 38.8 & 10.1 & 53.2 \\
\hline $\mathbf{T}_{10}-125 \% \mathrm{NPK}+\mathrm{Zn}$ & 84.8 & 1078.4 & 320 & 39.1 & 10.1 & 56.3 \\
\hline $\mathbf{T}_{11}-125 \% \mathrm{NPK}+\mathrm{Zn}+\mathrm{Mn}$ & 85.1 & 1079.3 & 324 & 39.4 & 10.2 & 57.9 \\
\hline $\mathbf{T}_{12}-125 \% \mathrm{NPK}+\mathrm{Zn}+\mathrm{Mn}+\mathrm{Fe}$ & 86.6 & 1081.5 & 330 & 40.1 & 10.4 & 58.7 \\
\hline $\begin{array}{l}\mathbf{T}_{13}-100 \% \text { NPK + FYM+ PSB+ Azotobactor } \\
+\mathrm{Zn}+\mathrm{Fe}+\mathrm{Mn}\end{array}$ & 85.3 & 1080.2 & 327 & 39.7 & 10.2 & 58.4 \\
\hline $\begin{array}{l}\mathbf{T}_{14}-50 \% \mathrm{~N}+100 \% \mathrm{PK}+\mathrm{FYM}+\mathrm{PSB}+ \\
\text { Azotobactor+Zn }+\mathrm{Fe}+\mathrm{Mn}+\mathrm{LCC} \\
\text { based N top dressing }\end{array}$ & 77.5 & 1018.7 & 280 & 37.5 & 10.0 & 53.0 \\
\hline $\mathrm{CD}(\mathbf{P}=0.05)$ & 7.2 & 52.1 & 20.7 & 0.8 & 0.6 & 2.6 \\
\hline
\end{tabular}

Table. 2 Total nitrogen, phosphorus, potassium, zinc, manganese and iron uptake in wheat as influenced by different nutrient options

\begin{tabular}{|c|c|c|c|c|c|c|}
\hline Treatment & $\begin{array}{c}\text { Total nitrogen } \\
\text { uptake } \\
\left(\mathrm{kg} \mathrm{ha}^{-1}\right)\end{array}$ & $\begin{array}{c}\text { Total } \\
\text { phosphorus } \\
\text { uptake }\left(\mathrm{kg} \mathrm{ha}^{-1}\right)\end{array}$ & $\begin{array}{l}\text { Total potassium } \\
\text { uptake }\left(\mathrm{kg} \mathrm{ha}^{-1}\right)\end{array}$ & $\begin{array}{l}\text { Total zinc } \\
\text { uptake } \\
\left(\mathrm{g} \mathrm{ha}^{-1}\right)\end{array}$ & $\begin{array}{c}\text { Total } \\
\text { manganese } \\
\text { uptake }(g \text { ha } \\
\left.1^{\prime}\right)\end{array}$ & $\begin{array}{c}\text { Total iron } \\
\text { uptake } \\
\left(\mathrm{g} \mathrm{ha}^{-1}\right)\end{array}$ \\
\hline $\mathbf{T}_{1}$ - Control & 64.4 & 10.0 & 35.2 & 193.3 & 129.4 & 675.0 \\
\hline $\mathbf{T}_{2}-100 \% \mathrm{NPK}$ & 111.1 & 19.3 & 73.0 & 449.7 & 322.3 & 1498.9 \\
\hline $\mathbf{T}_{3}-75 \% \mathrm{NPK}+\mathrm{FYM}$ & 115.3 & 21.1 & 76.8 & 466.1 & 333.5 & 1536.0 \\
\hline $\mathbf{T}_{4}-75 \% \mathrm{NPK}+\mathrm{FYM}+\mathrm{PSB}+$ Azotobactor & 117.5 & 22.0 & 79.1 & 478.5 & 340.0 & 1557.2 \\
\hline $\mathbf{T}_{5}-100 \% \mathrm{NPK}+\mathrm{Zn}$ & 121.2 & 22.9 & 81.8 & 491.5 & 350.2 & 1572.4 \\
\hline $\mathbf{T}_{\mathbf{6}}-100 \% \mathrm{NPK}+\mathrm{Zn}+\mathrm{Mn}$ & 128.5 & 24.8 & 91.7 & 515.2 & 365.2 & 1621.9 \\
\hline $\mathbf{T}_{7}-100 \% \mathrm{NPK}+\mathrm{Zn}+\mathrm{Mn}+\mathrm{Fe}$ & 131.6 & 26.5 & 94.9 & 524.7 & 374.5 & 1664.6 \\
\hline $\mathbf{T}_{\mathbf{8}^{-}} 75 \% \mathrm{NPK}+\mathrm{FYM}+\mathrm{PSB}+$ Azotobactor+Zn $+\mathrm{Fe}+\mathrm{Mn}$ & 126.7 & 24.8 & 87.8 & 511.5 & 361.4 & 1628.0 \\
\hline $\mathbf{T}_{9}-125 \% \mathrm{NPK}$ & 131.6 & 27.1 & 98.6 & 516.2 & 360.2 & 1650.9 \\
\hline $\mathbf{T}_{10}-125 \% \mathrm{NPK}+\mathrm{Zn}$ & 140.5 & 28.9 & 102.7 & 557.8 & 379.8 & 1711.7 \\
\hline $\mathbf{T}_{11}-125 \% \mathrm{NPK}+\mathrm{Zn}+\mathrm{Mn}$ & 143.9 & 30.7 & 106.3 & 576.6 & 394.1 & 1749.4 \\
\hline $\mathbf{T}_{12}-125 \% \mathrm{NPK}+\mathrm{Zn}+\mathrm{Mn}+\mathrm{Fe}$ & 155.0 & 34.3 & 111.6 & 600.8 & 409.7 & 1791.5 \\
\hline $\mathbf{T}_{13}-100 \%$ NPK + FYM+ PSB+ Azotobactor+Zn +Fe +Mn & 149.0 & 31.1 & 108.9 & 592.2 & 401.1 & 1749.0 \\
\hline $\begin{array}{l}\mathbf{T}_{14}-50 \% \mathrm{~N}+100 \% \mathrm{PK}+\mathrm{FYM}+\mathrm{PSB}+\text { Azotobactor } \\
+\mathrm{Zn}+\mathrm{Fe}+\mathrm{Mn}+\mathrm{LCC} \text { based N top dressing }\end{array}$ & 124.7 & 24.0 & 93.1 & 504.3 & 357.4 & 1614.9 \\
\hline $\mathrm{CD}(\mathrm{P}=\mathbf{0 . 0 5})$ & 12.1 & 4.3 & 10.7 & 31.5 & 20.7 & 35.6 \\
\hline
\end{tabular}


Table.3 Organic carbon, Soil pH, EC, Bulk density, Particle density and Net return as influenced by different nutrient options

\begin{tabular}{|c|c|c|c|c|c|c|}
\hline Treatment & $\begin{array}{c}\text { Organic } \\
\text { carbon } \\
(\%)\end{array}$ & $\begin{array}{c}\text { Soil } \\
\text { pH }\end{array}$ & $\underset{\left(\mathbf{d S m}^{-1}\right)}{\mathbf{E C}}$ & $\begin{array}{l}\text { Bulk density } \\
(\mathrm{g} / \mathrm{cc})\end{array}$ & $\begin{array}{l}\text { Particle density } \\
(\mathrm{g} / \mathrm{cc})\end{array}$ & $\begin{array}{l}\text { Net returns } \\
\left(\text { Rs ha }^{-1}\right)\end{array}$ \\
\hline $\mathbf{T}_{1^{-}}$Control & 0.39 & 8.19 & 0.47 & 1.53 & 2.66 & 24740 \\
\hline $\mathbf{T}_{2}-100 \% \mathrm{NPK}$ & 0.41 & 8.10 & 0.49 & 1.55 & 2.64 & 66385 \\
\hline $\mathbf{T}_{4}-75 \% \mathrm{NPK}+\mathrm{FYM}+\mathrm{PSB}+$ Azotobactor & 0.48 & 7.71 & 0.51 & 1.47 & 2.62 & 70123 \\
\hline $\mathbf{T}_{5}-100 \% \mathrm{NPK}+\mathrm{Zn}$ & 0.40 & 7.90 & 0.52 & 1.50 & 2.65 & 71080 \\
\hline $\mathbf{T}_{6}-100 \% \mathrm{NPK}+\mathrm{Zn}+\mathrm{Mn}$ & 0.42 & 7.81 & 0.51 & 1.50 & 2.64 & 72900 \\
\hline $\mathbf{T}_{9}-125 \% \mathrm{NPK}$ & 0.46 & 7.75 & 0.53 & 1.48 & 2.65 & 74374 \\
\hline $\mathbf{T}_{10}-125 \% \mathrm{NPK}+\mathrm{Zn}$ & 0.47 & 7.74 & 0.55 & 1.47 & 2.64 & 79079 \\
\hline $\mathbf{T}_{11}-125 \% \mathrm{NPK}+\mathrm{Zn}+\mathrm{Mn}$ & 0.48 & 7.73 & 0.57 & 1.46 & 2.64 & 80168 \\
\hline $\mathbf{T}_{12}-125 \% \mathrm{NPK}+\mathrm{Zn}+\mathrm{Mn}+\mathrm{Fe}$ & 0.50 & 7.72 & 0.59 & 1.46 & 2.65 & 81349 \\
\hline $\mathbf{T}_{13}-100 \%$ NPK + FYM+ PSB+ Azotobactor+Zn +Fe+Mn & 0.53 & 7.68 & 0.62 & 1.43 & 2.63 & 80170 \\
\hline $\begin{array}{l}\mathbf{T}_{14}-50 \% \mathrm{~N}+100 \% \mathrm{PK}+\mathrm{FYM}+\mathrm{PSB}+\text { Azotobactor }+\mathrm{Zn} \\
+\mathrm{Fe}+\mathrm{Mn}+\mathrm{LCC} \text { based N top dressing }\end{array}$ & 0.48 & 7.71 & 0.53 & 1.45 & 2.63 & 71260 \\
\hline
\end{tabular}

\section{Soil properties}

Soil $\mathrm{pH}$ did not differ significantly by the nutrient management practices. Numerically the maximum soil $\mathrm{pH}$ value (8.19) was observed in the control plot. Lowest soil $\mathrm{pH}$ (7.68) was recorded with $100 \%$ NPK + $\mathrm{FYM}+\mathrm{PSB}+$ Azotobactor $+\mathrm{Zn}+\mathrm{Fe}+\mathrm{Mn}$. The maximum soil EC value (0.62) was observed in $100 \% \mathrm{NPK}+\mathrm{FYM}+\mathrm{PSB}+$ Azotobactor $+\mathrm{Zn}+\mathrm{Fe}+\mathrm{Mn}$. Lowest soil EC (0.47) was recorded in Control plot. Numerically the maximum Bulk density value (1.55) was observed in $100 \%$ NPK plot. Lowest Bulk density (1.43) was recorded $100 \%$ NPK + FYM + PSB + Azotobactor + Zn $+\mathrm{Fe}+\mathrm{Mn}$ (Table 3). Numerically the maximum Particle density value (2.66) was observed in Control plot. Lowest Particle density (2.62) was recorded $75 \%$ NPK + FYM + PSB+ Azotobactor. Studies conducted by various workers have established the fact of maintenance of soil physical and chemical properties in terms of improved organic content, soil pH, EC, Bulk density and particle density in soil by application of organic manures in combination with chemical fertilizers in different ratio Singh et al., (2008) and Verma et al., (2009).

\section{Soil organic carbon}

Organic carbon in soil varied significantly among different nutrient treatment. Maximum carbon content was recorded in 100\% NPK along with FYM, biofertilizers, Zn, Mn and $\mathrm{Fe}(0.53)$ was statistically at par with $125 \%$ $\mathrm{NPK}+\mathrm{Zn}+\mathrm{Mn}+\mathrm{Fe}$ and $50 \% \mathrm{~N}+100 \% \mathrm{PK}$ $+\mathrm{FYM}+\mathrm{PSB}+$ Azotobactor $+\mathrm{Zn}+\mathrm{Fe}+\mathrm{Mn}$ + LCC based $\mathrm{N}$ top dressing (0.50 and 0.48) and significantly higher to control (Table 3 ). Studies conducted by various workers have established the fact of maintenance of soil fertility in terms of improved organic content and available nutrients in soil by application of organic manures in combination with chemical fertilizers in different ratio Singh $e t$ al., (2008) and Verma et al., (2009).

\section{Profitability}

Net return was observed highest in treatment $125 \% \mathrm{NPK}+\mathrm{Zn}+\mathrm{Mn}+\mathrm{Fe}$ Rs. 81349 closely followed by $100 \%$ NPK along with FYM, biofertilizers, $\mathrm{Zn}, \mathrm{Mn}$ and $\mathrm{Fe}$ of Rs. 80170. The lowest net return was observed in control plots (Table 3). The result on current studies showed that cost of cultivation was marginally higher when the nutrients were 
applied in combination. Due to higher grain yield, the net income was also higher with use of organic and inorganic fertilizers over $100 \%$ NPK. Similar result was also reported by Bhaduri \& Gautam (2012) and Lone et al., (2011)

The highest growth characters recorded with $125 \% \mathrm{NPK}+\mathrm{Zn}+\mathrm{Mn}+\mathrm{Fe}$ of was similar to the treatment of $100 \%$ NPK along with FYM, biofertilizers, $\mathrm{Zn}, \mathrm{Mn}$ and $\mathrm{Fe}$ and higher than $100 \%$ NPK and control. Although application of $125 \% \mathrm{NPK}+\mathrm{Zn}+\mathrm{Mn}+$ Fe yielded more among all the nutrient management options but it was found at par with $100 \%$ NPK along with FYM, biofertilizers, $\mathrm{Zn}$, Mn and Fe in grain yield, protein content and net return. In view the buildup of Soil organic carbon in soil, and uptake of macro and micro nutrients, application of $100 \%$ NPK along with FYM, biofertilizers, $\mathrm{Zn}, \mathrm{Mn}$ and Fe was found best among all nutrient management options. Keeping in view the sustainability of soil health $100 \%$ NPK along with FYM, biofertilizers, $\mathrm{Zn}, \mathrm{Mn}$ and Fe proved better. Thus $100 \%$ NPK along with FYM, biofertilizers, $\mathrm{Zn}, \mathrm{Mn}$ and $\mathrm{Fe}$ may be suggested for good performance of wheat crop and sustainability of soil health and crop yield in future.

\section{Acknowledgements}

This work has been executed at the Crop research centre of Sardar Vallabhbhai Patel University of Agriculture and Technology, Meerut, Uttar Pradesh, India under the Department of Agronomy. We are grateful to the authorities of the University for all support in execution of this experiment.

\section{References}

Ashutosh Barthwal, Bhardwaj, A.K., Chaturvedi, S. and Pandiaraj, T. 2013. Site specific NPK recommendation in wheat (Triticum aestivum) for sustained crop and soil productivity in mollisols of Tarai region. Indian J Agron, 58 (2): 208-214.

Bhaduri, D. and Gautam, P. 2012. Balanced use of fertilizers and FYM to enhance nutrient recovery and productivity of wheat (Triticum aestivum cv UP-2382) in a mollisol of Uttrakhand. Intl. $J$ Agric. Biotech, 5 (4): 435-439.

Cakmak, I. 2012. Harvest plus Zinc Fertilizer Project: Harvest Zinc. Better Crops, 96 (2): 17-19.

FAO, 2013. Food and Agriculture organization of the united nation, (http:// www.fao. org/ statistic/en/).

Gupta Lal P, Bisht P S and Pandey P C. 2000. Integrated organic and inorganic $\mathrm{N}$ management in low land rice. Oryza 75 (2): $120-3$.

Hasan, M. A. and Kamal, A. M. 1998. Effect of fertilizer on grain yield and $m$ grain protein content of wheat. J. Nat. Sci. council of Sri Lanka, 26(1): 1-8

Jakhar, Parveen, Singh, Jagdev and Nanwal, R.K. 2006. Growth analysis of wheat (Triticum aestivum L.) as influenced by planting methods, bio-fertilizers and nitrogen levels. Haryana J Agron, 22 (1):77-78.

Jat, G., Majumdar, S.P., Jat, N.K. and Majundar, S.P. 2013. Potassium and zinc fertilization of wheat (Triticum aestvum) in Western arid zone of India. Indian J Agron, 58 (1): 67-71.

Kumar, V. and Ahlawat, I.P.S. 2004. Carry over effect of bioferilizers and nitrogen applied to wheat (Triticum aestivum) and direct applied $\mathrm{N}$ in maze (Zea mays) in wheat maize cropping systems. Indian J Agron, 49(4): 233-236.

Lone, A. A., Mahdi, S. S., Bhat, M. I., Bhat, R. A., Faisul-ur-Rasool and Singh, O.P. 2011. Productivity and phosphorus use efficiency of wheat (Triticum aestivum L.) as influenced phosphorus under subtropical conditions of U.P. Environ Eco, 29(3A): 1321-1325.

Meena, B.L., Phogat, B.S., Jat, S.L., Singh, A.K. and Sharma, H.B. 2012. Effects of planting and integrated nutrient management systems on root phenology and grain yield of wheat. Etennded Summaries: $3^{\text {rd }}$ 
International Agronomy Congress, Nov. 26-30, New Delhi, India.

Mubarak, T. and Singh, K.N. 2011. Nutrient management and productivity of wheat (Triticum aestivum) based cropping system in temperate zone. Indian J Agron, 56 (3): 176-181.

Pandey, S. N. and Sinha, B.N. 2009. Function of mineral nutrition in plant. Plant physiology Edn. $4^{\text {th }}$ pp $120-139$.

Pandey.: I.B.; Dwivedi, D.K. and Pandey, R.K 2009. Integrated nutrient management for sustaining wheat (Triticum aestivum) production under late sown condition. Indian J Agron, 54 (3): 306 - 309.

Rathor, S.A. and Sharma, N.L. 2010. Effect of integrated nutrient management on productivity and nutrient uptake in wheat and soil fertility. Asian J Soil Sci. 4(2): 208210.

Rehman, S., Shad, K.K., Muhammad, F., Rehman, A., Khan, A.Z., Amanullah, Rehman, A., Saljoki, Muhammad, Z. and Khalil, I.H. 2010. Phenology, leaf area index and grain yield of rain fed wheat influenced by organic and Inorganic fertilizer. Pak. J. Bot., 42(5): 3671-3685.

Sen, A., Pandey, M.D., Sharma, S.N. Singh, R.K. Kumar, A., Shukla, P. and Srivastava, V.K. 2003. Surface seeding of wheat as affected by seed rate and nitrogen level. Indian $J$ Agri Sci, 73 (9): 509-511.

Sepat, R.N., Rai, R.K. and Dhar, S. 2010. Planting systems and integrated nutrient management for enhanced wheat (Triticum aestivum) productivity. Indian J Agron, 55 (2): 114-118.

Shivay, Y.S.; Prasad, R. and Rahal, A. 2008. Relative efficiency of zinc oxide and zinc sulphate-enriched urea for spring wheat. Nutriet CycAgro Ecosys, 82: 259-264.

Singh, F., Kumar, R. and Pal, S. 2008. Integrated nutrient management in rice-wheat cropping system for sustainable productivity. J Indian soc soil sci., 56 (2): 205-208.

Singh, R. and Agarwal, S.K. 2001. Growth and yield of wheat as influenced by levels of FYM and nitrogen. Indian J.Agron., 46(3): 462-467.

Singh, R.K., Singh, S.K. and Singh, L.B. 2007. Integrated nitrogen management in wheat (Triticum aestivum). Indian J Agron, 52 (2): 124-126.

Thakaral, S.K., Kadian, U.S. and Kumar, S. 2003. Effect of different organic and inorganic fertilizer levels on yield and yield attributes of wheat. Haryana, J. Agron., 19 (1): 6062.

Tisdale, S.L. Nelson, W.L. Beaton, J.D and Havlin, J.L. 1995. Soil fertility and fertilizer.Prevtice-Hall of India Pvt. Ltd., New Delhi

Tulasa Ram and Mir, S.S. 2006. Effect of integrated nutrient management on yield and yield attributing characters of wheat (Triticum aestivum). Indian J Agron, 51(3): 189-192.

Verma, G. and Mathur, A.K. 2009. Effect of integrated nutrient management on active pools of soil organic matter under maizewheat system of a Typic Haplustept. $J$ Indian Soc Soil Sci., 57 (3): 317-322.

Verma, G., Mathur, A.K., Bhandari, S.C. and Kanthaliya, P.C. 2010. Long term effect of integrated nutrient management on properties of a typic haplustept under maize-wheat cropping system. JIndian Soc Soil Sci., 58 (3):299-302.

\section{How to cite this article:}

Vineet Singh, N.S. Rana, Ravindra Kumar, Vivek, B.P. Dhyani, R.K. Naresh, Arun Kumar and Nihal Chandra Mahajan. 2017. Integration of Organic and Mineral Nutrient Sources Enhances Wheat Productivity, Soil Health and Profitability in western Uttar Pradesh. Int.J.Curr.Microbiol.App.Sci. 6(10): 3089-3097. doi: https://doi.org/10.20546/ijcmas.2017.610.364 